\title{
CYP450 Metabolism of a Semisynthetic Naphthoquinone, an Anticancer Drug Candidate, by Human Liver Microsomes
}

\author{
Edna M. A. Costa, ${ }^{a}$ Daniel B. Carrão, ${ }^{b}$ Jade L. M. Bucci, ${ }^{b}$ Anderson R. M. Oliveira,${ }^{b, c}$ \\ Tallita M. Machado, ${ }^{d}$ Vitor F. Ferreira, ${ }^{\circledR e}$ Émerson S. Lima, ${ }^{\circledR d}{ }^{d}$ Marne C. Vasconcellos ${ }^{d}$ \\ and Igor R. S. Magalhães ${ }^{\circledR * a}$
}

${ }^{a}$ Núcleo de Estudos em Farmacocinética, Faculdade de Ciências Farmacêuticas, Universidade Federal do Amazonas, 69077-000 Manaus-AM, Brazil

${ }^{b}$ Departamento de Química, Faculdade de Filosofia, Ciências e Letras de Ribeirão Preto, Universidade de São Paulo, 14040-901 Ribeirão Preto-SP, Brazil

'Instituto Nacional de Tecnologias Alternativas para Detecção, Avaliação Toxicológica e Remoção de Contaminantes Emergentes e Radioativos (INCT-Datrem), Instituto de Química, Universidade Estadual Paulista (UNESP), CP 355, 14800-900 Araraquara-SP, Brazil

${ }^{d}$ Laboratório de Atividade Biológica, Faculdade de Ciências Farmacêuticas, Universidade Federal do Amazonas, 69077-000 Manaus-AM, Brazil

${ }^{e}$ Laboratório de Sintese de Carboidratos e Nucleosídeos, Universidade Federal Fluminense, 24220-900 Niterói-RJ, Brazil

CNFD (6b,7-dihydro-5H-cyclopenta[ $b]$ naphtho[2,1- $d]$ furan-5,6(9aH)-dione) is a semisynthetic naphthoquinone derived from lawsone that has cytotoxic action in different tumor lines and anticancer activity in vivo. Therefore, this molecule is a relevant candidate for drug development, but there is still no information on its human metabolism and systemic elimination. This study aimed to investigate the in vitro metabolism of this naphthoquinone by human liver microsomes. Initially, in order to determine the in vitro enzymatic kinetic parameters, a high performance liquid chromatography (HPLC) method to quantify the CNFD was developed and validated. In addition, the enzymatic kinetic data, the predicted pharmacokinetic in vivo parameters and the phenotyping study were presented. The main metabolism sites and metabolites have been suggested in silico. The developed HPLC method was linear, reproducible, selective, accurate, and stable. The enzymatic kinetic parameters revealed a sigmoidal profile. In vitro to in vivo extrapolation hepatic metabolic clearance was $10.39 \mathrm{~mL} \mathrm{~min}^{-1} \mathrm{~kg}^{-1}$ protein and the liver extraction rate was $51 \%$. The clearance in vivo associated with a hepatic extraction ratio indicates that the hepatic metabolism is the main route of elimination. Although all cytochrome P450 enzymes evaluated metabolized CNFD, CYP2C9 and CYP3A4 showed higher metabolic capacity. For the first time, metabolism studies of CNFD were demonstrated.

Keywords: lawsone, drug development, biotransformation, pharmacokinetics, preclinical drug evaluation

\section{Introduction}

Cancer is one of the main public health problems worldwide. It is the first or second leading cause of premature death in 134 countries. ${ }^{1,2}$ Generally, the

*e-mail: imagalhaes@ufam.edu.br

Editor handled this article: Teodoro S. Kaufman chemotherapy treatment currently available for cancer is still inefficient, with high toxicity and low selectivity. Thus, the search for new, more effective and selective, and low toxic antineoplastic drugs is necessary. ${ }^{3,4}$ In this context, plant-derived molecules, such as naphthoquinones, are promising candidates for new anticancer agents. ${ }^{5}$

Naphthoquinones are secondary metabolites of plants that have considerable biological activities, such 
as antimicrobial, antifungal, antiviral, antimalarial, and antitumor activity. ${ }^{5-8}$ Among natural naphthoquinones, lawsone (2-hydroxy-1,4-naphthoquinone), found in the leaves of Lawsonia inermis L. (Lythraceae), a plant known as henna, is widely used as natural dye for skin and hair. ${ }^{5,9}$ Lawsone derivatives are attractive for the development of new drugs due to the broad spectrum of their biological activities. ${ }^{1}$ Several pharmacological properties of them have already been reported, such as antibacterial,${ }^{10}$ antifungal ${ }^{11}$ and antitumor. ${ }^{12}$

The CNFD (6b,7-dihydro-5H-cyclopenta[b] naphtho[2,1-d]furan-5,6(9aH)-dione) (Figure 1) is a naphthoquinone synthesized from lawsone with remarkable antifungal activity. ${ }^{13}$ In addition, this derivative has also demonstrated potential as an antineoplastic agent in different cell lines, especially in human breast adenocarcinoma cells MCF-7 with an half-maximal inhibitory concentration $\left(\mathrm{IC}_{50}\right)$ of less than $1 \mu \mathrm{mol} \mathrm{L} \mathrm{L}^{-1}$. CNFD has the ability to induce cell apoptosis. In an in vivo study using a murine model of melanoma (B16F10), CNFD led to tumor regression in animals (inhibition of 46,50 , and $52 \%$ at doses of 10,30 and $60 \mathrm{mg} \mathrm{kg}^{-1}$ day $^{-1}$, respectively), becoming a candidate for an antineoplastic drug. ${ }^{14} \mathrm{~A}$ patent, related to the antineoplastic properties of CNFD, was already deposited under the registration number BR10201700717. ${ }^{15}$

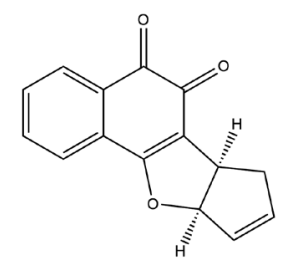

Figure 1. Chemical structure of CNFD (6b,7-dihidro-5H-ciclopenta[ $b]$ nafto[2,1- $d]$ furano-5,6(9aH)-dione).

During the development of new drugs, drug candidates must undergo pre-clinical studies to obtain the greatest possible knowledge about the pharmacological, pharmacokinetic properties, and toxicity ${ }^{16}$ In this context, the contribution of cytochrome P450 (CYP450) enzymes to the metabolism of this new candidate is fundamental, since these enzymes are responsible for the metabolism of most commercialized drugs. ${ }^{17}$ In vitro and in silico studies during drug discovery can be useful to predict issues related to drug safety, such as pharmacokinetic parameters and drug-drug interactions. ${ }^{18,19}$

Anti-tumor drugs have low specificity, that is, they do not only affect cancer cells, but also affect normal cells. The metabolites formed by the metabolism of these drugs can induce several adverse effects, including other serious problems and even the patient's death. ${ }^{20}$
Despite the antitumor activity of CNFD, its metabolic pathway within the human body has not been reported. Thus, this study aimed to evaluate the in vitro metabolism of CNFD by CYP450 enzymes, including elucidation of the enzymatic kinetic profile, identification of the main CYP450 isoforms responsible for its metabolism, and prediction of in vivo pharmacokinetic parameters. In addition, predict the CNFD metabolism sites by CYP enzymes and the possible metabolites formed in silico.

\section{Experimental}

Reagents and solvents

The lawsone derivative, CNFD (6b,7-dihydro$5 H$-cyclopenta[ $b]$ naphtho[2,1-d]furan-5,6(9aH)-dione), was kindly provided by Prof Dr Vitor Francisco Ferreira. ${ }^{13}$ The standard stock solution of CNFD was prepared at $4000 \mu \mathrm{mol} \mathrm{L}^{-1}$ in methanol. Phenacetin ( $\geq 98.0 \%$ ), which was used as internal standard (IS), was acquired from Sigma-Aldrich (St. Louis, USA). The standard stock solution of phenacetin was prepared at $200 \mu \mathrm{mol} \mathrm{L}^{-1}$ in methanol. Human plasma was obtained from SigmaAldrich (St. Louis, USA), and human liver microsomes (HLMs) (150-donor pool) and recombinant CYP450 (rCYP450) isoforms (Supersomes ${ }^{\circledR}$ ) were purchased from Corning Life Science (Phoenix, USA). Ultrapure water $(18.2 \mathrm{M} \Omega \mathrm{cm})$ was obtained from a Milli-Q Direct-Q3 UV (Millipore, Bedford, USA). HPLC (high-performance liquid chromatography) grade solvents methanol and ethyl acetate were obtained from Panreac (Castellar Del Vallès, Barcelona, Spain). The glucose-6-phosphate sodium salt, glucose-6-phosphate dehydrogenase, and $\beta$-nicotinamide adenine dinucleotide phosphate hydrate $\left(\mathrm{NADP}^{+}\right)$ components of the NADPH ( $\beta$-nicotinamide adenine dinucleotide phosphate) cofactor system were acquired from Sigma-Aldrich (St. Louis, USA). The solutions were prepared in a tris- $\mathrm{KCl}$ buffer (tris(hydroxymethyl) aminomethane $0.05 \mathrm{~mol} \mathrm{~L}^{-1}$ and $\mathrm{KCl} 0.15 \mathrm{~mol} \mathrm{~L}^{-1}$, $\mathrm{pH}$ 7.4) at the following concentrations: glucose6-phosphate $\left(50 \mathrm{mmol} \mathrm{L}^{-1}\right)$, and glucose-6-phosphate dehydrogenase $\left(8.0 \mathrm{U} \mathrm{mL}^{-1}\right)$, and $\mathrm{NADP}^{+}\left(2.5 \mathrm{mmol} \mathrm{L}^{-1}\right)$ and stored at $-20{ }^{\circ} \mathrm{C}$. Other analytical grade reagents used were tris(hydroxymethyl) aminomethane (JT Baker, Phillipsburg, USA), Cremophor ${ }^{\circledR}$ (Sigma-Aldrich, St. Louis, USA), potassium chloride (Mallinckrodt Chemicals, Phillipsburg, USA), sodium phosphate monobasic, and sodium phosphate dibasic (Synth, Diadema, Brazil). 


\section{Microsomal incubation conditions}

The microsomal incubation medium consisted of the substrate (CNFD), NADPH cofactor system, HLMs or rCYP450, and phosphate buffer $\left(0.1 \mathrm{~mol} \mathrm{~L}^{-1}, \mathrm{pH} 7.4\right)$ with $0.1 \%(\mathrm{~m} / \mathrm{v})$ of Cremophor $^{\circledR}$, in a final volume of $200 \mu \mathrm{L}$. The samples were pre-incubated for $5 \mathrm{~min}$ at $37^{\circ} \mathrm{C}$, in a water bath. The metabolism was initiated by the addition of the NADPH cofactor system. After the incubation time, the reaction was stopped with the addition of $1 \mathrm{~mL}$ of ethyl acetate and $50 \mu \mathrm{L}$ of internal standard (IS). Next, the samples were shaken for $15 \mathrm{~min}$ at $1500 \mathrm{rpm}$ in a Vibrax $\mathrm{VXR}^{\circledR}$ agitator (IKA, Staufen, Germany) and centrifuged at $1800 \times \mathrm{g}$ for $15 \mathrm{~min}$ at $4{ }^{\circ} \mathrm{C}$ in a HIMAC CF15D2 centrifuge (Hitachi, Tokyo, Japan). Then, the organic phase was collected and evaporated in a Concentrator Plus speed vacuum (Eppendorf, Hamburg, Germany). The final residue was reconstituted in the mobile phase and analyzed by HPLC.

HPLC

A Shimadzu HPLC system (Kyoto, Japan), which comprised a DGU-20A5 online degasser, a LC-20AT solvent pump unit, a SIL-10AF automatic injector, a CTO-20A column oven, an SPD-M20A (190-800 nm) diode array detector, and a CBM-20A system controller, was employed. The separation was carried out using an Ascentis Express C18 (3.0 $\mathrm{mm} \times 4.6 \mathrm{~mm}, 2.7 \mu \mathrm{m})$ guard column and an Ascentis Express Fused Core C18 (100 mm $\times 4.6 \mathrm{~mm}$, $2.7 \mu \mathrm{m}$ ) analytical column (Supelco, Bellefonte, USA). The mobile phase consisted of methanol:water $(55: 45, \mathrm{v} / \mathrm{v})$ at flow rate of $0.8 \mathrm{~mL} \mathrm{~min}{ }^{-1}$. The injection volume was $30 \mu \mathrm{L}$ and the temperature of analysis was $30^{\circ} \mathrm{C}$. The detection was performed at 260 and $247 \mathrm{~nm}$ for CNFD and IS, respectively. Data were collected using the LC solution software 1.25 SP1 (Shimadzu, Kyoto, Japan).

\section{Method validation}

The analytical method was validated according to the ANVISA guidelines on bioanalytical method validation. ${ }^{21}$ The evaluated parameters were linearity, limit of quantification, carryover, selectivity, accuracy, precision, and stability.

Linearity was assessed for the following concentrations of CNFD: 0.3 (lower limit of quantification (LLOQ)), 2.56 (low quality control (LQC)), 10.07 (quality control (QC)), 20.14 (medium quality control (MQC)), 80.59 (high quality control (HQC)) and $100.73 \mu \mathrm{mol} \mathrm{L}{ }^{-1}$ (upper limit of quantification (ULOQ)). The calibration curves were constructed plotting the normalized area versus concentration of CNFD. The analytical curve was weighted (weighting factor $1 / \mathrm{X}^{2}$ ) and the determination coefficient $\left(r^{2}\right)$ and linear regression equation were calculated. In addition, the linearity was assessed using an analysis of variance (ANOVA) lack-of-fit test, calculating the values of $F$ and $p$ with Minitab 16 Statistical Software ${ }^{22}$ (State College, USA). The LLOQ was determined by analyzing the lowest concentration of the CNFD with relative standard deviation (RSD) and relative error (RE) lower than $20 \%$. Carryover was evaluated assessing the presence of interferences in the CNFD and IS retention time. Selectivity was evaluated analyzing a blank sample of the microsomal medium (without CNFD and IS) to assess the presence of matrix interferents. Intraday $(n=5)$ and interday $(n=5)$ accuracy and precision were evaluated for the LLOQ, LQC, MQC, HQC and ULOQ levels. The results were acceptable if RSD and RE were lower than $20 \%$ for the LLOQ and lower than $15 \%$ for the other concentrations levels. Stability was evaluated at incubation conditions $\left(37^{\circ} \mathrm{C}\right.$ for $\left.60 \mathrm{~min}\right)$ and auto-injector for $24 \mathrm{~h}$, for the LQC and ULOQ samples.

\section{Enzymatic kinetic}

The enzymatic kinetic of the metabolism of CNFD by CYP450 enzymes $(n=4)$ was determined at initial velocity conditions (microsomal protein content of $0.20 \mathrm{mg} \mathrm{mL}^{-1}$ and incubation time of $60 \mathrm{~min}$ ) for the following concentration range of CNFD: $0.3-80 \mu \mathrm{mol} \mathrm{L} \mathrm{L}^{-1}$. After metabolism, the samples were analyzed and quantified by HPLC, using a calibration curve $(n=3)$, prepared on the same day of the study. The rate of enzymatic reaction, for each concentration of CNFD, was determined by the metabolized concentration of CNFD by the protein concentration and incubation time. The obtained results were plotted on a graph of rate of enzymatic reaction versus concentration of CNFD and analyzed by non-linear regression in enzymatic models, using the GraphPad Prism 6 software ${ }^{23}$ (San Diego, USA). The enzymatic kinetic parameters of the metabolism reaction were obtained and the in vitro intrinsic clearance $\left(\mathrm{CL}_{\mathrm{INT} \text {, in vitro }}\right)$ was calculated using equation $1 .{ }^{24}$ Then, the $\mathrm{CL}_{\mathrm{INT} \text {, in vitro }}$ was extrapolated to the in vivo intrinsic liver clearance $\left(\mathrm{CL}_{\mathrm{INT} \text {, in vivo }}\right)$, according to equation $2 .{ }^{25}$

$\mathrm{CL}_{\mathrm{INT}, \text { in vitro }}=\frac{\mathrm{V}_{\mathrm{MAX}}}{\mathrm{S}_{50}} \times \frac{(\mathrm{h}-1)}{\mathrm{h}(\mathrm{h}-1)^{1 / \mathrm{h}}}$

where $\mathrm{CL}_{\mathrm{INT} \text {, in vitro }}$ : in vitro intrinsic clearance; $\mathrm{V}_{\mathrm{MAX}}$ : maximum velocity of the enzymatic reaction; $S_{50}$ : concentration of the substrate where $\mathrm{V}$ corresponds to half of $\mathrm{V}_{\text {MAX }}$; h: Hill coefficient. 
$\mathrm{CL}_{\mathrm{INT}, \text { in vivo }}=\mathrm{CL}_{\mathrm{INT} \text {, in vitro }} \times \frac{40 \mathrm{mg} \text { microsomal protein }}{\mathrm{g} \text { liver }} \times \frac{21.4 \mathrm{~g} \text { liver }}{\mathrm{kg} \text { body }}$

where, $\mathrm{CL}_{\mathrm{INT} \text {, in vivo }}$ in vivo intrinsic clearance and $\mathrm{CL}_{\mathrm{INT} \text {, in vitro }}$ in vitro intrinsic clearance.

\section{Prediction of in vivo pharmacokinetic parameters}

For the prediction of the in vivo pharmacokinetic parameters, the percentage of binding of CNFD to plasma proteins and microsomal proteins were determined using the substrate concentration below the $S_{50}$ value determined in enzymatic kinetic. The microsomal medium was prepared with the substrate, HLMs $\left(0.2 \mathrm{mg} \mathrm{mL}^{-1}\right)$ and phosphate buffer $\left(0.1 \mathrm{~mol} \mathrm{~L}^{-1}, \mathrm{pH} 7.4\right)$ with $0.1 \%$ $(\mathrm{m} / \mathrm{v})$ of Cremophor ${ }^{\circledR}$. The plasma medium was made of substrate and human plasma (protein concentration $42 \mathrm{mg} \mathrm{mL}^{-1}$ ). Control samples (in the absence of plasma or microsomal proteins) were prepared with the substrate and phosphate buffer $\left(0.1 \mathrm{~mol} \mathrm{~L}^{-1}, \mathrm{pH} 7.4\right)$ with $0.1 \%(\mathrm{~m} / \mathrm{v})$ of Cremophor ${ }^{\circledR}$. All samples were incubated at $37{ }^{\circ} \mathrm{C}$ for $60 \mathrm{~min}$. After incubation, the samples were subjected to ultracentrifugation at $150060 \times \mathrm{g}$ and $4{ }^{\circ} \mathrm{C}$ for $3 \mathrm{~h}$, in a Beckman Optima XL-100K (Brea, CA, USA). The supernatant was collected, subjected to the sample preparation, and analyzed using HPLC. The unbonded fraction of the substrate $\left(\mathrm{f}_{\mathrm{u}}\right)$ was determined according to equation $3 .{ }^{26}$

$f_{u}=\frac{C_{A}}{C_{C}}$

where $\mathrm{f}_{\mathrm{u}}$ : substrate unbonded fraction, $\mathrm{C}_{\mathrm{A}}$ : sample concentration and $\mathrm{C}_{\mathrm{C}}$ : control concentration.

Using the obtained results, unbonded fraction of the

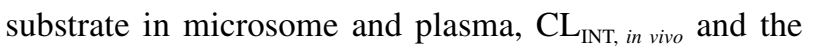
hepatic blood flow (Q) $20 \mathrm{~mL} \mathrm{~min}{ }^{-1} \mathrm{~kg}^{-1},{ }^{27}$ the in vivo pharmacokinetic parameters hepatic clearance $\left(\mathrm{CL}_{\mathrm{H}}\right)$ and hepatic extraction rate $\left(\mathrm{E}_{\mathrm{H}}\right)$ were calculated using equations 4 and 5 , respectively. ${ }^{25}$

$$
\mathrm{CL}_{\mathrm{H}}=\frac{\mathrm{Q} \frac{\mathrm{f}_{\mathrm{u}, \mathrm{p}}}{\mathrm{f}_{\mathrm{u}, \mathrm{m}}} \mathrm{CL}_{\mathrm{INT} \text {, in vivo }}}{\mathrm{Q}+\left(\frac{\mathrm{f}_{\mathrm{u}, \mathrm{p}}}{\mathrm{f}_{\mathrm{u}, \mathrm{m}}} \mathrm{CL}_{\mathrm{INT} \text {, in vivo }}\right)}
$$

where $\mathrm{CL}_{\mathrm{H}}$ : hepatic clearance, $\mathrm{Q}$ : hepatic blood flow, $\mathrm{f}_{\mathrm{u}, \mathrm{p}}$ : unbonded fraction of the substrate in plasma, $\mathrm{f}_{\mathrm{u}, \mathrm{m}}$ : unbonded fraction of the substrate in microsomal medium and $\mathrm{CL}_{\mathrm{INT} \text {, in vivo }}$ in vivo intrinsic clearance.
$\mathrm{E}_{\mathrm{H}}=\frac{\mathrm{CL}_{\mathrm{H}}}{\mathrm{Q}}$

where $\mathrm{E}_{\mathrm{H}}$ : hepatic extraction rate, $\mathrm{CL}_{\mathrm{H}}$ : hepatic clearance, Q: hepatic blood flow.

\section{CYP450 phenotyping}

The determination of the main human CYP450 isoforms responsible for CNFD metabolism was performed using rCYP450. The substrate was incubated with a rCYP450 isoform (50 $\mathrm{pmol} \mathrm{mL}^{-1}$ ) (rCYP1A2, rCYP2B6, rCYP2C8, rCYP2C9, rCYP2C19, rCYP2D6, rCYP2E1, rCYP3A4 or rCYP3A5). Controls containing insect cells instead of the rCYP450 isoform were prepared. The mixture was incubated at $37^{\circ} \mathrm{C}$ for $60 \mathrm{~min}$ and the reaction was stopped by the addition of ethyl acetate. Sample preparation and HPLC analysis were performed as previously described. The samples were quantified using analytical curves prepared on the same day and the reaction rates were determined. To obtain the normalized rate (TN) (equation 6), the abundance of each CYP450 isoform in human liver microsomes was considered. The total normalized rate (TNR) for each isoform was obtained by the ratio of TN to the sum of the $\mathrm{TN}$ of all isoforms of CYP450 (equation 7). ${ }^{28}$

$\mathrm{TN}=\mathrm{V}_{\mathrm{rCY} 450} \times$ abundance ${ }_{(\mathrm{CYP} 450)}$

where, TN: normalized rate of each isoform of CYP450 and $\mathrm{V}_{\mathrm{rCYP} 450}$ : rate of enzymatic reaction for each isoform of CYP450.

$\operatorname{TNR}(\%)=\frac{\mathrm{TN} \times 100}{\sum \mathrm{TN}}$

where, TNR: percentage of the total normalized rate and $\mathrm{TN}$ : normalized rate.

\section{Prediction of metabolism using SMARTCyp software}

The prediction of CNFD metabolism sites by the enzymes CYP3A4, CYP2D6 and CYP2C9 was performed using the SMARTCyp online server. ${ }^{29}$ According to this database, the lower the activation energies, the more likely a site is to be metabolized. ${ }^{30}$

CNFD was submitted to the online server MetaTox, ${ }^{31}$ through a two-dimensional drawing in a database to predict the possible sites of metabolism, from phase I reactions (oxidation, reduction and hydroxylation) and phase 2 (conjugation). ${ }^{32}$ 


\section{Results}

\section{Method validation}

Chromatogram of the CNFD analysis can be seen in Figure 2. The calibration curve developed showed adequate linearity for studies evaluating the metabolism of CNFD in microsomal medium. The lack-of-fit test showed that the analytical curve obeys a linear model. The lower limit of quantification of CNFD in microsomal medium was $0.3 \mu \mathrm{mol} \mathrm{L}{ }^{-1}$. The method was selective and carry over was not observed. The intraday and interday precision and accuracy were lower than $7 \%$ for all concentrations. Stability results guaranteed the stability of CNFD in incubation conditions and auto-injector, since both the RE and RSD were lower than $8 \%$ (Table 1).

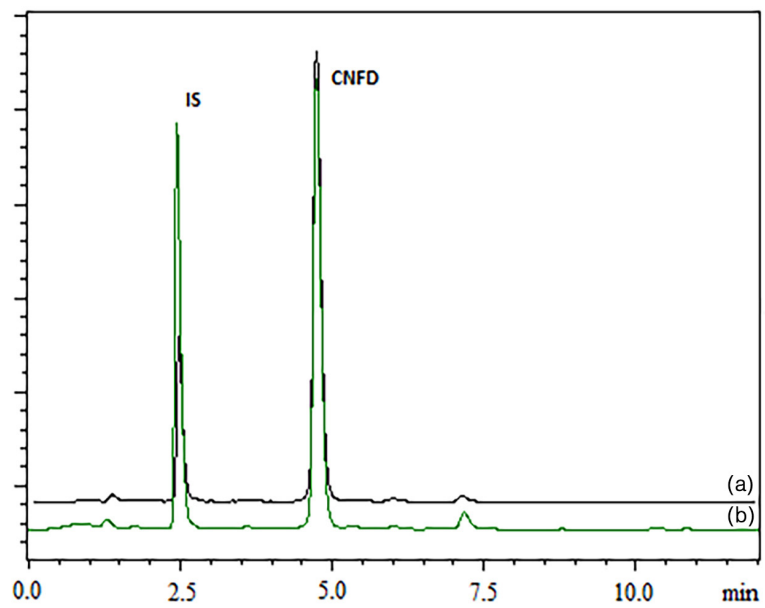

Figure 2. Representative chromatogram of the CNFD analysis. Chromatographic conditions (HPLC-DAD): Ascentis Express C18 $(3.0 \mathrm{~mm} \times 4.6 \mathrm{~mm}, 2.7 \mu \mathrm{m})$ guard column and an Ascentis Express Fused Core C18 $(100 \mathrm{~mm} \times 4.6 \mathrm{~mm}, 2.7 \mu \mathrm{m})$ analytical column, mobile phase methanol:water $(55: 45, \mathrm{v} / \mathrm{v})$, flow rate of $0.8 \mathrm{~mL} \mathrm{~min}^{-1}$, injection volume was $30 \mu \mathrm{L}$ and the temperature was $30^{\circ} \mathrm{C}$. The detection was performed at 260 (a) for CNFD and $247 \mathrm{~nm}$ (b) for IS.

\section{Enzymatic kinetic}

The enzymatic kinetic of CNFD metabolism by HLMs demonstrated a sigmoidal kinetic profile (Figure 3). The enzymatic parameters were $\mathrm{V}_{\mathrm{MAX}}=8.6 \pm 1.7 \mathrm{nmol} \mathrm{mg}^{-1}$ protein $\mathrm{min}^{-1}, \mathrm{~S}_{50}=137.1 \pm 36.4 \mu \mathrm{mol} \mathrm{L} \mathrm{L}^{-1}$ and a Hill coefficient of $1.23 \pm 0.05$. The Eadie-Hofstee plot resulted in a convex curve.

\section{Prediction of in vivo pharmacokinetic parameters}

The binding of CNFD to microsomal and plasma proteins was 4 and $37 \%$, respectively. The predicted parameters in vitro intrinsic clearance, in vivo intrinsic
Table 1. Confidence limits obtained for the analysis the CNFD method in microsomal media

\begin{tabular}{|c|c|c|}
\hline \multicolumn{3}{|l|}{ Linearity $(n=5)$} \\
\hline Linear equation / $\left(\mu \mathrm{mol} \mathrm{L}{ }^{-1}\right)$ & \multicolumn{2}{|c|}{$y=0.1027 x+0.0027$} \\
\hline Range / $\left(\mu \mathrm{mol} \mathrm{L}{ }^{-1}\right)$ & \multicolumn{2}{|c|}{$0.3-100.73$} \\
\hline Determination coefficient $\left(\mathrm{r}^{2}\right)$ & \multicolumn{2}{|c|}{0.9994} \\
\hline Lack of fit & \multicolumn{2}{|c|}{$F=1.73 ; p=0.208$} \\
\hline \multicolumn{3}{|l|}{ Limit of quantification $(\mathrm{n}=5)$} \\
\hline Concentration / $\left(\mu \mathrm{mol} \mathrm{L} \mathrm{L}^{-1}\right)$ & \multicolumn{2}{|c|}{0.3} \\
\hline Precision RSD / \% & \multicolumn{2}{|c|}{7} \\
\hline Accuracy RE / \% & \multicolumn{2}{|c|}{7} \\
\hline \multicolumn{3}{|l|}{ Stability $(\mathrm{n}=3)$} \\
\hline \multicolumn{3}{|l|}{ Incubation $37^{\circ} \mathrm{C}$ for $60 \mathrm{~min}$} \\
\hline$\overline{\text { Concentration / }\left(\mu \mathrm{mol} \mathrm{L} \mathrm{L}^{-1}\right)}$ & \multicolumn{2}{|c|}{2.56} \\
\hline Precision RSD / \% & \multicolumn{2}{|c|}{0} \\
\hline Accuracy RE / \% & \multicolumn{2}{|c|}{-8} \\
\hline Concentration / $\left(\mu \mathrm{mol} \mathrm{L} \mathrm{L}^{-1}\right)$ & \multicolumn{2}{|c|}{80.59} \\
\hline Precision RSD / \% & \multicolumn{2}{|c|}{2} \\
\hline Accuracy RE / \% & \multicolumn{2}{|c|}{1} \\
\hline \multicolumn{3}{|l|}{ Incubation auto-injector for $24 \mathrm{~h}$} \\
\hline Concentration / $\left(\mu \mathrm{mol} \mathrm{L} \mathrm{L}^{-1}\right)$ & \multicolumn{2}{|c|}{2.56} \\
\hline Precision RSD / \% & \multicolumn{2}{|c|}{1} \\
\hline Accuracy RE / \% & \multicolumn{2}{|c|}{-3} \\
\hline Concentration / $\left(\mu \mathrm{mol} \mathrm{L}{ }^{-1}\right)$ & \multicolumn{2}{|c|}{80.59} \\
\hline Precision RSD / \% & \multicolumn{2}{|c|}{1} \\
\hline \multirow[t]{3}{*}{ Accuracy RE / \% } & \multicolumn{2}{|c|}{0} \\
\hline & \multicolumn{2}{|c|}{ Precision RSD $(n=5) / \%$} \\
\hline & Intraday & Interday \\
\hline $0.3 \mu \mathrm{mol} \mathrm{L}^{-1}$ & 7 & 6 \\
\hline $2.56 \mu \mathrm{mol} \mathrm{L}-1$ & 3 & 2 \\
\hline $20.14 \mu \mathrm{mol} \mathrm{L}^{-1}$ & 3 & 3 \\
\hline $80.59 \mu \mathrm{mol} \mathrm{L}^{-1}$ & 5 & 3 \\
\hline \multirow[t]{3}{*}{$100.73 \mu \mathrm{mol} \mathrm{L}^{-1}$} & 7 & 5 \\
\hline & \multicolumn{2}{|c|}{ Accuracy RE $(\mathrm{n}=5) / \%$} \\
\hline & Intraday & Interday \\
\hline $0.3 \mu \mathrm{mol} \mathrm{L}^{-1}$ & 7 & 3 \\
\hline $2.56 \mu \mathrm{mol} \mathrm{L}-1$ & 0 & 0 \\
\hline $20.14 \mu \mathrm{mol} \mathrm{L}^{-1}$ & 4 & 4 \\
\hline $80.59 \mu \mathrm{mol} \mathrm{L}-1$ & 6 & 6 \\
\hline $100.73 \mu \mathrm{mol} \mathrm{L}^{-1}$ & 0 & -5 \\
\hline
\end{tabular}

RSD: relative standard deviation; RE: relative error.

clearance, hepatic clearance and hepatic extraction ratio were expressed in Table 2.

\section{CYP450 phenotyping}

rCYP450 were used to determine the role of each CYP450 isoform involved in the metabolism of CNFD. As show in Figure 4, all the evaluated rCYP450 isoforms contributed to CNFD metabolism. 

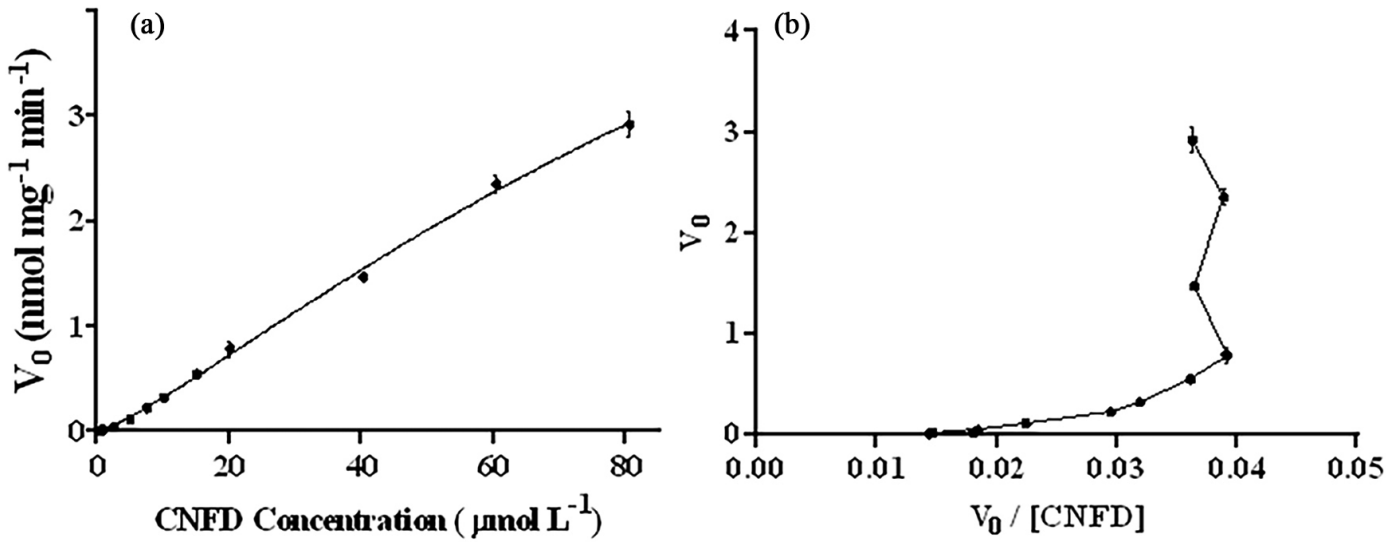

Figure 3. (a) In vitro kinetic profile (sigmoidal plot) of CNFD catalyzed by CYP enzymes. (b) Eadie-Hofstee graph.

Table 2. Determination of the free fraction not bound to microsomal and plasma proteins and in vivo pharmacokinetic parameters

\begin{tabular}{lccccc}
\hline $\mathrm{f}_{\mathrm{u}, \mathrm{m}} / \%$ & $\mathrm{f}_{\mathrm{u}, \mathrm{p}} / \%$ & $\mathrm{CL}_{\mathrm{INT}, \text { in vitro }} /\left(\mu \mathrm{L} \mathrm{mg}^{-1} \mathrm{~min}^{-1}\right)$ & $\mathrm{CL}_{\mathrm{INT}, \text { in vivo }} /\left(\mathrm{mL} \mathrm{min}^{-1} \mathrm{~kg}^{-1}\right)$ & $\mathrm{CL}_{\mathrm{H}} /\left(\mathrm{mL} \mathrm{min}^{-1} \mathrm{~kg}^{-1}\right)$ & $\mathrm{E}_{\mathrm{H}} / \%$ \\
\hline 96 & 63 & 38.5 & 32.98 & 10.39 & 51 \\
\hline
\end{tabular}

$\mathrm{f}_{\mathrm{u}, \mathrm{m}}$ : unbonded fraction of the substrate in microsomal medium; $\mathrm{f}_{\mathrm{u}, \mathrm{p}}$ : unbonded fraction of the substrate in plasma medium; $\mathrm{CL}_{\mathrm{INT}, \text { in vitro }}$ : in vitro intrinsic clearance; $\mathrm{CL}_{\mathrm{INT} \text {, in vivo }}$ in vivo intrinsic clearance; $\mathrm{CL}_{\mathrm{H}}$ : hepatic clearance; $\mathrm{E}_{\mathrm{H}}$ : hepatic extraction rate.

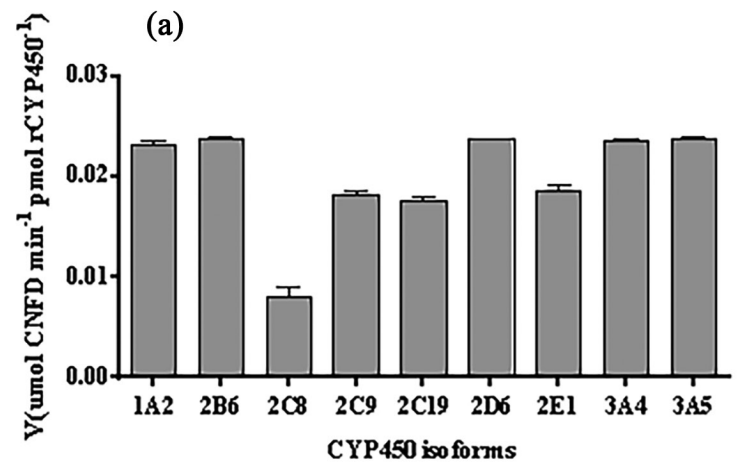

(b)

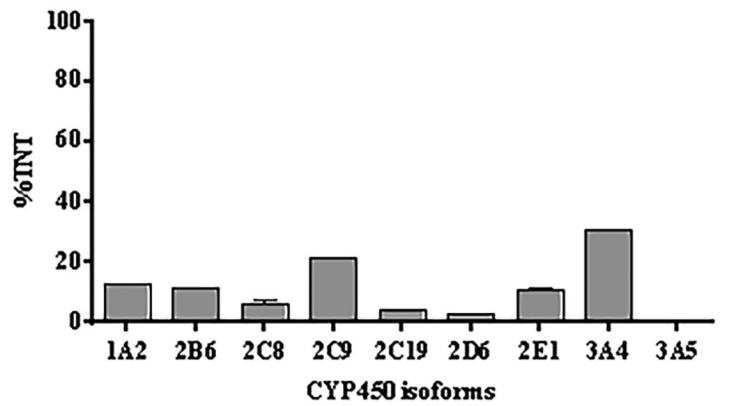

Figure 4. Determination of the CYP isoform involving CNFD metabolism using recombinant enzymes. (a) Velocity of the enzymatic reaction. (b) Total normalized rate.

\section{Prediction of metabolism using SMARTCyp and Metatox software}

The prediction of CNFD metabolism sites by CYP enzymes was evaluated by the SMARTCyp server. The platform classified the relevance of color metabolism and the main site of metabolism by CYP3A4 and CYP2D6 was carbon 8. For CYP2C9, the detected metabolism site was carbon 12. The results are available in Table 3 and Figure 5.

The metabolic chemical reactions predicted by the CYP450 enzyme are phase I reactions, where a greater prediction was observed for hydrogenation, epoxidation and oxidation reactions. Among the predicted metabolites, the M1 metabolite obtained by the hydrogenation reaction, was the one with the highest probability of occurrence. The results are available in Figure 6.
Table 3. Prediction of CNFD metabolism using the online platform (values were computed by SMARTCyp server)

\begin{tabular}{lccc}
\hline Ranking (CYP3A4) & Atom & $\begin{array}{c}\text { Score / } \\
\left(\mathrm{KJ} \mathrm{mol}^{-1}\right)\end{array}$ & $\begin{array}{c}\text { Energy / } \\
\left(\mathrm{KJ} \mathrm{mol}^{-1}\right)\end{array}$ \\
\hline 1 (red) & $\mathrm{C} 8$ & 39.8 & 46.2 \\
2 (orange) & $\mathrm{C} 9$ & 55.7 & 62.2 \\
3 (yellow) & $\mathrm{C} 12$ & 56.2 & 65.6 \\
\hline Ranking (CYP2D6) & & & \\
\hline 1 (red) & $\mathrm{C} 8$ & 59.2 & 46.2 \\
2 (orange) & $\mathrm{C} 12$ & 64.2 & 65.6 \\
3 (yellow) & $\mathrm{C} 11$ & 71.1 & 65.6 \\
\hline Ranking (CYP2C9) & & & \\
\hline 1 (red) & $\mathrm{C} 12$ & 81.9 & 65.6 \\
2 (orange) & $\mathrm{C} 8$ & 87.1 & 46.2 \\
3 (yellow) & $\mathrm{C} 11$ & 88 & 65.6 \\
\hline
\end{tabular}


(a)

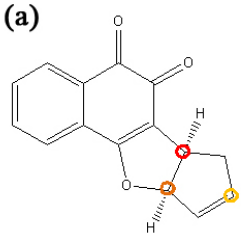

(b)

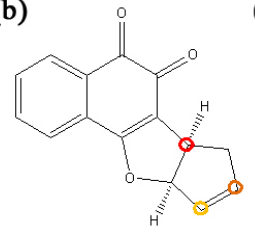

(c)

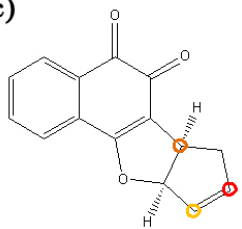

Figure 5. Probable sites of drug metabolism prompted by CYP3A4 (a) CYP2D6 (b) CYP2C9 (c), according to the online platform. The color code can be found in Table 3 .

\section{Discussion}

The development of a new drug undergoes pre-clinical studies, including the evaluation of the contribution of CYP450 enzymes in the metabolism of this new drug candidate. ${ }^{33,34}$ Through these studies, it is possible to predict the enzymes involved in metabolism and drug interactions. ${ }^{35}$ Since the CNFD is still in the early stages of the drug development process, the present study reports for the first-time evidence of its metabolism by CYP450 enzymes.

The enzymatic kinetics obtained showed a sigmoidal profile, with positive cooperativity for having exhibited $\mathrm{h}$ above 1 (one) ( $\mathrm{h}=1.23)$ and the Eadie-Hofstee plot resulted in a convex curve. ${ }^{36}$ This result shows that the binding of the substrate with the enzyme occurs in more than one active site. ${ }^{37}$ In addition, the velocity of the enzymatic reaction may be the sum of the catalysis of several CYP enzymes, as the phenotyping study showed the contribution of all isoforms to the metabolism of CNFD, except for CYP3A5. The kinetic parameters obtained were used to determine the in vitro intrinsic clearance.

From the data obtained in enzymatic kinetics, it was possible to extrapolate these results in vitro to in vivo, predicting the pharmacokinetic parameters. Liver clearance is extremely important during the development of a new drug, as it is related to drug exposure and halflife. ${ }^{19}$ The rate of hepatic extraction $\left(\mathrm{E}_{\mathrm{H}}=51 \%\right)$ indicates that part of the drug undergoes first-pass metabolism. ${ }^{38}$ In addition, liver clearance $\left(\mathrm{CL}_{\mathrm{H}}=10.39 \mathrm{~mL} \mathrm{~min}{ }^{-1} \mathrm{~kg}^{-1}\right)$ indicates that CNFD is rapidly metabolized by the liver. CNFD was weakly bound to microsomal proteins, thereby minimizing non-specific binding. In addition, only $37 \%$ of the CNFD was bound to plasma proteins. In drug development, the low binding of a molecule with plasma proteins is desirable since the risk of competitive interactions is reduced.

As previously mentioned, the phenotyping study suggests the mediation of the evaluated CYP isoforms, mainly CYP3A4 and CYP2C9. The metabolism by multiple enzymes is also important for an ideal drug. ${ }^{35}$ If any enzymatic pathway is impaired, other enzymes can carry out the metabolism of the drug, ensuring the elimination from the organism. Furthermore, the metabolism performed by different CYP enzymes is a positive result as more than one pathway may provide drug conversion, which minimizes the risk of interactions.

CNFD is a naphthoquinone derivative and naphthoquinones are known to have inhibitory potential in some human isoforms of CYP450, in addition to which cytochrome $\mathrm{P} 450$ and $\mathrm{P} 450$ reductase enzymes can promote reductive activation of quinones by one or two electron reductions, providing the production of unstable semiquinone..$^{39,40}$

In silico approaches have been increasingly used to predict the metabolism of new drug candidates, allowing for cost and time savings. ${ }^{18}$ One recent example in the literature was the analysis with the three different SMARTCyp algorithms in the study of the CYP-mediated metabolism

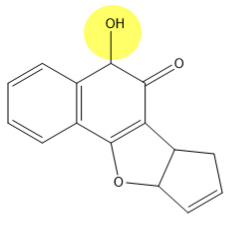

M1

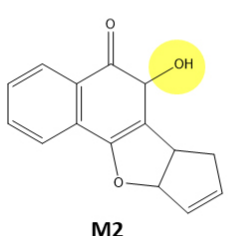

Hydrogenation

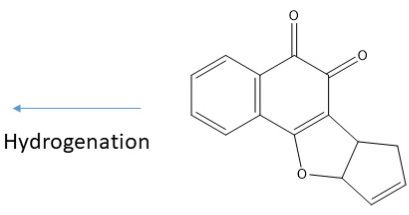

CNFD

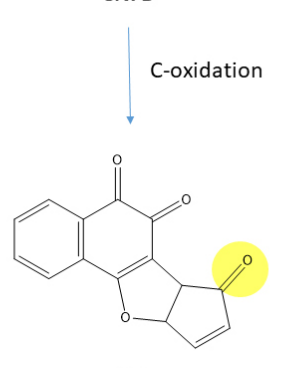

Epoxidation

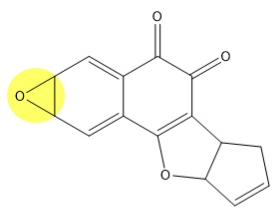

M3

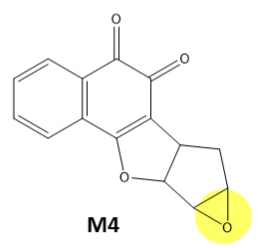

M5

Figure 6. Prediction of CNFD metabolites and their respective chemical reactions. Hydrogenation: M1 (93.93\%) and M2 (88.42\%); epoxidation: M3 (84.82\%) and M4 (71.09\%); C-oxidation: M5 (67.39\%). 
of DA-Phen, a new dopaminergic agent. ${ }^{41}$ The prediction of the metabolism sites by the SMARTCyp platform for CYP3A4, CYP2D6 and CYP2C9 occurred through the use of algorithms that use the activation energy of cytochrome P450 for reaction with a molecule. ${ }^{30,34}$ In this study, the main metabolism sites have been suggested, providing important information for the identification of metabolites. Although the predictive approaches developed cannot completely replace standard protocols, this strategy can provide an earlier decision-making process until the necessary data is available.

The bioanalytical method developed and validated is simple and has been successfully used for its intended purpose. It was not possible to detect CNFD metabolites, which requires the use of more sensitive and selective assays employing liquid chromatography mass spectrometry (LC-MS) in order to determine, isolate and elucidate these molecules. However, the chromatographic method is fully compatible with mass spectrometry, being a starting point for future studies. Since CNFD is a drug candidate, assessing the toxicity of these metabolites is of great importance. In addition, the enzyme inhibition study may indicate the likely drug interactions that may occur.

\section{Conclusions}

In summary, the metabolism of the CNFD drug candidate was characterized for the first time. The data established in the kinetic study were used to predict important pharmacokinetic parameters, determining liver clearance. CYP450 is involved in CNFD metabolism, with all enzymes showing important roles, especially CYP3A4 and CYP2C9. Metabolism sites were predicted. These results may be useful for future in vitro studies, as well as for clinical studies.

\section{Acknowledgments}

The financial support from the project entitled "Studies of in vitro metabolism of the derivative of lawsone", approved within the scope of the MCTI/CNPq/Universal 14/2014 - Track A - National Council for Scientific and Technological Development is acknowledged. The authors are also thankful to São Paulo Research Foundation (grants No. 2016/15680-5, and 2018/07534-4), Conselho Nacional de Desenvolvimento Científico e Tecnológico (CNPq - INCT-DATREM) (grant No. 465571/2014-0) and Coordenação de Aperfeiçoamento de Pessoal de Nível Superior - Brazil (CAPES) - Finance Code 001 for financial support.

\section{Author Contributions}

Anderson R. M. Oliveira and Igor R. S. Magalhães were responsible for conceptualization; Edna M. A. Costa, Tallita M. Machado, Jade L. M. Bucci, Daniel B. Carrão for methodology and formal analysis; Anderson R. M. Oliveira and Igor R. S. Magalhães for funding acquisition; Vitor F. Ferreira, Émerson S. Lima for resources; Marne C. Vasconcellos, Anderson R. M. Oliveira and Igor R. S. Magalhães for writing original draft and writing-review and editing; Igor R. S. Magalhães for investigation, supervision and project administration.

\section{References}

1. Schepetkin, I. A.; Karpenko, A. S.; Khlebnikov, A. I.; Shibinska, M. O.; Levandovskiy, I. A.; Kirpotina, L. N.; Danilenko, N. V.; Quinn, M. T.; Eur. J. Med. Chem. 2019, 183, 111719.

2. World Health Organization (WHO); Global Cancer Observatory; 2020, https://gco.iarc.fr/, accessed in February 2022.

3. Ottoni, F. M.; Gomes, E. R.; Pádua, R. M.; Oliveira, M. C.; Silva, I. T.; Alves, R. J.; Bioorg. Med. Chem. Lett. 2020, 30, 126817.

4. Zhang, Y.; Luo, Y. H.; Piao, X. J.; Shen, G. N.; Wang, J. R.; Feng, Y. C.; Li, J. Q.; Xu, W. T.; Zhang, Y.; Zhang, T.; Wang, C. Y.; Jin, C. H.; Bioorg. Med. Chem. 2019, 27, 1577.

5. Darvin, S. S.; Esakkimuthu, S.; Toppo, E.; Balakrishna, K.; Paulraj, M. G.; Pandikumar, P.; Ignacimuthu, S.; Al-Dhabi, N. A.; Environ. Toxicol. Pharmacol. 2018, 61, 87.

6. da Silva, M. N.; Ferreira, V. F.; de Souza, M. C. B. V.; Quim. Nova 2003, 26, 407.

7. Salunke-Gawali, S.; Pereira, E.; Dar, U. A.; Bhand, S.; J. Mol. Struct. 2017, 1148, 435.

8. da Silva, A. M. P.; de Paiva, S. R.; Figueiredo, M. R.; Kaplan, M. A. C.; Rev. Fitos 2012, 7, 207.

9. Rahmoun, N. M.; Boucherit-Otmani, Z.; Boucherit, K.; Benabdallah, M.; Villemin, D.; Choukchou-Braham, N.; Med. Mal. Infect. 2012, 42, 270.

10. Sharma, A.; Santos, I. O.; Gaur, P.; Ferreira, V. F.; Garcia, C. R. S.; da Rocha, D. R.; Eur. J. Med. Chem. 2013, 59, 48.

11. Nittayananta, W.; Pangsomboon, K.; Panichayupakaranant, P.; Chanowanna, N.; Chelae, S.; Vuddhakul, V.; Sukhumungoon, P.; Pruphetkaew, N.; J. Oral Pathol. Med. 2013, 42, 698.

12. Oramas-Royo, S.; Torrejón, C.; Cuadrado, I.; Hernández-Molina, R.; Hortelano, S.; Estévez-Braun, A.; de Las Heras, B.; Bioorg. Med. Chem. 2013, 21, 2471.

13. Freire, C. P. V.; Ferreira, S. B.; de Oliveira, N. S. M.; Matsuura, A. B. J.; Gama, I. L.; da Silva, F. D. C.; de Souza, M. C. B. V.; Lima, E. S.; Ferreira, V. F.; MedChemComm. 2010, 1, 229.

14. de Almeida, P. D. O.; Jobim, G. S. B.; Ferreira, C. C. S.; Bernardes, L. R.; Dias, R. B.; Sales, C. B. S.; Valverde, L. F.; Rocha, C. A. G.; Soares, M. B. P.; Bezerra, D. P.; da Silva, F. C.; Cardoso, M. F. C.; Ferreira, V. F.; Brito, L. F.; de Sousa, L. 
P.; de Vasconcellos, M. C.; Lima, E. S.; Chem.-Biol. Interact. 2021, 343, 109444.

15. Universidade Federal Fluminense; BR10201700717 2017.

16. Vohora, D.; Singh, G. In Pharmaceutical Medicine and Translational Clinical Research; Academic Press: Cambridge, USA, 2017.

17. Fakunle, E. S.; Loring, J. F.; Trends Mol. Med. 2012, 18, 709.

18. Kazmi, S. R.; Jun, R.; Yu, M. S.; Jung, C.; Na, D.; Comput. Biol. Med. 2019, 106, 54.

19. Moreira, F. L.; Habenschus, M. D.; Barth, T.; Marques, L. M. M.; Pilon, A. C.; da Silva Bolzani, V.; Vessecchi, R.; Lopes, N. P.; de Oliveira, A. R. M.; Sci. Rep. 2016, 6, 33646.

20. Chagas, C. M.; Moss, S.; Alisaraie, L.; Int. J. Pharm. 2018 , 549, 133.

21. Agência Nacional de Vigilância Sanitária (ANVISA); Resolução No. 27, de 17 de maio de 2012, Dispõe sobre $O s$ Requisitos Mínimos para a Validação de Métodos Bioanalíticos Empregados em Estudos com Fins de Registro e Pós-Registro de Medicamentos; Diário Oficial da União (DOU), Brasília, de 22/05/2012, available at https://bvsms.saude.gov.br/bvs/ saudelegis/anvisa/2012/rdc0027_17_05_2012.html, accessed in February 2022.

22. Minitab 16 Statistical Software; Minitab, Inc., State College, USA, 2010.

23. GraphPad Prism 6; Graph Pad Software, Inc., San Diego, USA, 2012.

24. Kramer, M. A.; Tracy, T. S. In Encyclopedia of Drug Metabolism and Interactions, vol. 1; Lyubimov, A. V., ed.; John Wiley \& Sons: Hoboken, USA, 2012, ch. 3.

25. Bowman, C. M.; Benet, L. Z.; Eur. J. Pharm. Sci. 2018, 123, 502.

26. Giuliano, C.; Jairaj, M.; Zafiu, C. M.; Laufer, R.; Drug Metab. Dispos. 2005, 33, 1319.
27. Damre, A. A.; Iyer, K. R. In Encyclopedia of Drug Metabolism and Interactions, vol. 3; Lyubimov, A. V., ed.; John Wiley \& Sons: Hoboken, USA, 2012, ch. 12.

28. Rodrigues, A. D.; Biochem. Pharmacol. 1999, 57, 465.

29. Montefiori, M.; Tran, K. P.; Jørgensen, F. S.; Olsen, L.; SMARTCyp; University of Copenhagen, Copenhagen, Denmark, 2019.

30. Rydberg, P.; Gloriam, D. E.; Zaretzki, J.; Breneman, C.; Olsen, L.; ACS Med. Chem. Lett. 2010, 1, 96.

31. Filimonov, D.; MetaTox; Institute of Biomedical Chemistry, Moscow, Russia, 2019.

32. Rudik, A. V.; Bezhentsev, V. M.; Dmitriev, A. V.; Druzhilovskiy, D. S.; Lagunin, A. A.; Filimonov, D. A.; Poroikov, V. V.; J. Chem. Inf. Model. 2017, 57, 638.

33. Park, E.; Kim, H. K.; Jee, J. H.; Hahn, S.; Jeong, S.; Yoo, J.; Toxicol. Appl. Pharmacol. 2019, 385, 114790.

34. Tyzack, J. D.; Kirchmair, J.; Chem. Biol. Drug Des. 2019, 93, 377.

35. Zhang, Z.; Tang, W.; Acta Pharm. Sin. B 2018, 8, 721.

36. Subramanian, M.; Tracy, T. S. In Encyclopedia of Drug Metabolism and Interactions, vol. 6; Lyubimov, A. V., ed.; John Wiley \& Sons: Hoboken, USA, 2012, ch. 9.

37. Seibert, E.; Tracy, T. S.; Enzyme Kinetics in Drug Metabolism: Fundamentals and Applications; Nagar, S.; Argikar, U. A.; Tweedie, D. J., eds.; Humana Press: New Jersey, 2014.

38. Mehvar, R.; Curr. Clin. Pharmacol. 2016, 11, 47.

39. Costa, M. C. A.; Carvalho, P. O. M.; Ferreira, M. M. C.; J. Chemom. 2019, 34, e3131.

40. Halicki, P. C. B.; Ferreira, L. A.; de Moura, K. C. G.; Carneiro, P. F.; del Rio, K. P.; Carvalho, T. S. C.; Pinto, M. C. F. R.; da Silva, P. E. A.; Ramos, D. F.; Front. Microbiol. 2018, 9, 673.

41. Sutera, F. M.; Giannola, L. I.; Murgia, D.; de Caro, V.; Comput. Biol. Chem. 2017, 71, 63. 